\title{
The Compliance of Intern Nursing Students With Isolation Precautions; During COVID-19 Pandemic Process
}

\section{COVID-19 Pandemi Sürecinde İntörn Hemşirelik Öğrencilerinin İzolasyon Önlemlerine Uyumu}

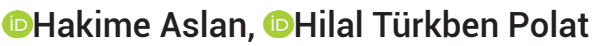 \\ Inonu University Faculty of Nursing, Department of Fundamentals of Nursing, Malatya, Turkey \\ Seydişehir Kamil Akkanat Faculty of Health Sciences, Department of Nursing, Konya, Turkey \\ Copyright@Author(s) - Available online at www.dergipark.org.tr/tr/pub/medr \\ Content of this journal is licensed under a Creative Commons Attribution-NonCommercial 4.0 International License.
}

\begin{abstract}
Aim: The present study was conducted to determine the level of compliance of intern nursing students with isolation precautions and the factors affecting them.

Material and Method: The research was carried out with fourth-year nursing students in the internship program in a university hospital between December 2020 and April 2021. The data were collected using the "Participant Information Form" and the "Isolation Precautions Compliance Scale".

Results: It was determined that the students received a total of $76.11 \pm 9.86$ points from the Isolation Precautions Compliance Scale. The statistical analysis indicated that there was no significant difference between the compliance with isolation precautions and the variables of age, gender, the type of the clinic, the training received about isolation precautions and providing care to the isolated patient $(p>0.05)$. However, it was found that the difference between the compliance with isolation precautions and the variables of the pandemic process and knowing the infection rate of the institution was significant $(p<0.05)$.

Conclusion: It was concluded that the compliance of the intern nurses with isolation precautions was quite high.
\end{abstract}

Keywords: Isolation, standard precaution, hospital infection, nurse

Öz

Amaç: Bu araştırma, intörn hemşirelik öğrencilerinin izolasyon önlemlerine uyum düzeyi ve etkileyen faktörleri belirlemek amacıyla yapılmıştır.

Materyal ve Metot: Bu araştırma bir üniversite hastanesinde intörnlük uygulamasına çıkan hemşirelik dördüncü sınıf öğrencileri ile Aralık 2020-Nisan 2021 tarihleri arasında yürütülmüştür. Veriler, "Katılımcı Tanıtım Formu" ve "İzolasyon Önlemlerine Uyum Ölçeği" kullanılarak toplanmıştır.

Bulgular. Öğrencilerin İzolasyon Önlemlerine Uyum Ölçeğinden toplam $76.11 \pm 9.86$ puan aldığı saptanmıştır. Yaş, cinsiyet, çalışılan klinik, izolasyon önlemleri ile ilgili eğitim alma ve izole edilen hastaya bakım verme değişkenleri ile izolasyon önlemlerine uyum arasındaki farkın istatistiksel olarak anlamlı olmadığı saptanmıştır ( $p>0.05)$. Ancak, çalışılan kurumun enfeksiyon hızını bilme durumu ve pandemi sürecinin izolasyon önlemlerine uyumu etkilediği belirlenmiştir $(p<0.05)$.

Sonuç: İntörn hemşirelerin izolasyon önlemlerine uyumlarının oldukça yüksek olduğu sonucuna varılmıştır.

Anahtar kelimeler. İzolasyon, standart önlem, hastane enfeksiyonu, hemşire

\section{INTRODUCTION}

Healthcare-associated infections are important factors that negatively affect the quality and output of healthcare services. Infections that develop within 48 hours or longer after hospitalization or develop within 30 days of discharge are stated to be nosocomial (1). The term "nosocomial" refers to any infection that a patient acquires from the hospital during receiving healthcare services (2). Healthcare-associatedinfectionscauseprolongedhospital stay of patients, a serious economic burden on patients and their families, and increased morbidity, mortality, and treatment costs $(3,4)$. Policies and guidelines at the national and international level on infection control provide recommendations on standard principles towards the control and prevention of healthcare-associated infections. 
Policies on infection control are evidence-based and aim to inform best practices and thereby optimize patient care and safety (5).

Infection control precautions should beimplemented within the scope of combating healthcare-associated infections. Those standard and elementary precautions aiming to prevent or minimize the risks of cross-infection include many applications such as ensuring hand hygiene, wearing gloves, using personal protective equipment, complying with aseptic technique, management of medical wastes including piercing-cutting tools, hospital/environmental cleaning, and appropriate antibiotic use. The secondary precautions are those applied together with the standard practices to prevent transmission from infected patients. These precautions are contact, droplet and respiratory isolation precautions and training of medical personnel. The tertiary precautions that are not routinely applied include applications such as disinfecting the environment or taking cultures from the environment when necessary (5-7).

All healthcare professionals are expected to have a high level of compliance with these control precautions to reduce the incidence of nosocomial infections, improve patient safety, and decrease the risk of infection (8). Healthcare workers should protect themselves and the patients they care for against infectious agents and take the necessary precautions. The most important factor in the development of infection is the attitudes and behaviors of health personnel. Nurses and nursing students, who are with the patient 24 hours a day, have important responsibilities in this regard. Nurses should have the most up-to-date information on the prevention and control of nosocomial infections, and provide effective care to patients by using this information in their practices (9). One of the infection control precautions is compliance with isolation precautions. Despite all the precautions taken in the world and in our country, the COVID-19 epidemic continues and the number of morbidity and mortality is increasing. The issue of compliance with isolation precautions in keeping the epidemic under control is particularly noteworthy (10). In the literature, there are studies assessing the level of compliance of health workers with isolation precautions and their compliance level is seen to be high $(11,12)$. However, in the literature review on compliance with isolation precautions during COVID-19 pandemic, a limited number of studies were found with the participation of intern nursing students (10). The infection control and the compliance with isolation precautions is a critical issue for all health workers including intern nursing students. Due to the scarcity of the studies conducted with intern nurses, the present study was decided to be carried out. It is important to evaluate the knowledge and attitudes of future health workers about isolation precautions and to complete their missing knowledge at this stage. The present study was carried out to determine the level of compliance of intern nursing students with isolation precautions and the factors affecting them.

\section{MATERIAL AND METHOD}

Research Type: The study is descriptive type.

\section{Place and date of the research}

The study was carried out with intern nursing students in a university hospital located east of Turkey between December 2020 and April 2021.

\section{Population and Sample}

The population of the study consisted of intern nursing students of the Faculty of Nursing at Inonu University who were in an internship program $(\mathrm{N}=248)$. Sample selection was not made, it was target to reach the whole population. The research was completed with 152 students who agreed to participate in the study and were accessible online. $61 \%$ of the population has been reached.

\section{Data Collection}

Two different data collection forms were used to collect the data. These are the "Participant Information Form" and the "Isolation Precautions Compliance Scale (IPCS)". The scale forms were prepared online by the researchers using Google Forms and distributed to the participants via WhatsApp. Necessary explanations about the research and written consent were attached to the first page of the form. The students who agreed to participate in the research were able to answer the survey questions. The scales took about 5-10 minutes to complete.

\section{Data Collection Tools}

\section{Participant Information Form}

In this form, besides the demographic characteristics of the students such as age and gender, there are also questions about isolation measures.

\section{Isolation Precautions Compliance Scale (IPCS)}

The IPCS was developed by Tayran and Ulupınar in 2011 and its validity and reliability were verified. The scale, consisting of 18 positive and negative statements, aims to measure the compliance of nurses and physicians with isolation precautions, is of 5-point Likert type. Each item on the scale is rated from $1=$ strongly disagree to $5=$ strongly agree. Negative statements on the scale $(5,7,12$ and 17) are scored backwards. The lowest score to be obtained from the scale is 18 , while the highest score to be obtained is 90 . It is regarded that as the score received increases, the level of compliance with isolation precautions rises. Although the developers of the scale suggested using the single-factor version of the scale, scores from four subdimensions were also taken in consideration in this study. While Tayran and Ulupınar determined the Cronbach's alpha value of the scale to be 0.85 (13), it was calculated to be 0.88 in the present study.

\section{Data Analysis}

In the analysis of data; The distribution of socio- 
demographic characteristics of the students was given by descriptive tests. The Kolmogorov-Smirnov test was used to evaluate the conformity of the data to the normal distribution. Non-parametric tests were applied in the statistical analysis because the data were not normally distributed $(p<0.05)$. The difference between sociodemographic characteristics of students and the total IPCS scores was determined using the Mann Whitney U and the Kruskal-Wallis $\mathrm{H}$ tests.

\section{Ethical Approval}

Ethical approval from the Health Sciences Scientific Research and Publication Ethics Committee of Inonu University (2021/1554), and institutional permission from the Deanship of the Faculty of Nursing were obtained before conducting the research. In addition, a written consent form was taken from the students who participated in the study.

\section{RESULTS}

The mean age of the students was $22.13 \pm 1.05$. Of the students $65.8 \%$ were female, $53.9 \%$ were interns in the internal medicine clinic, $73.7 \%$ stated that they received training for isolation precautions, $57.9 \%$ perceived their level of knowledge about isolation precautions as moderate, $67.1 \%$ did not know the infection rate of the institution they worked, $68.4 \%$ provided care to isolated patients during their time working, and $67.1 \%$ expressed that the pandemic process greatly affected the importance they attach to isolation precautions (Table 1).

Table 1. The distribution of socio-demographic characteristics of the students

Number (152)

Percentage (\%)

Age $(X \pm S D) \quad 22.13 \pm 1.05$

Gender

Female

Type of the clinic

Internal medicine

Pediatric

Have you received training on isolation precautions?

Yes

No

What do you think is your level of knowledge about isolation precautions and nosocomial infections?

Good

Moderate

Low

Do you know the infection rate of the institution you work?

Yes

No

Have you provided care for the isolated patient during your internship?

Yes

To what extent has the pandemic process affected the importance you attach to isolation precautions?

Greatly affected

Little affected

$\mathrm{X}$ : Mean, SD: Standard Deviation 
Table 2. Mean scores of Isolation Precautions Compliance Scale and its sub-dimensions

\begin{tabular}{|c|c|c|}
\hline Scale & Min-Max & $X \pm S D$ \\
\hline Transmission Route & $5.0-25.0$ & $21.23 \pm 3.45$ \\
\hline Work and Patient Safety & $16.0-30.0$ & $25.38 \pm 3.27$ \\
\hline Environmental Control & $4.0-20.0$ & $16.73 \pm 2.61$ \\
\hline Hand Hygiene and Glove Use & $6.0-15.0$ & $12.76 \pm 1.96$ \\
\hline IPCS Total & $34.0-89.0$ & $76.11 \pm 9.86$ \\
\hline X: Mean, SD: Standard Deviation & & \\
\hline $\begin{array}{l}\text { Table } 2 \text { shows the IPCS total and sub-dimension scores } \\
\text { of the students. It was observed that the mean total IPCS } \\
\text { score of the students was } 76.11 \pm 9.86 \text {, while transmission } \\
\text { route sub-dimension mean score was } 21.23 \pm 3.45 \text {, work } \\
\text { and patient safety was } 25.38 \pm 3.27 \text {, environmental control }\end{array}$ & \multicolumn{2}{|c|}{$\begin{array}{l}\text { was } 16.73 \pm 2.61 \text { and hand hygiene and glove use was } \\
12.76 \pm 1.96 \text {. Considering the fact that the maximum score } \\
\text { that can be obtained from the IPCS is } 90 \text {, it was observed } \\
\text { that the compliance level of the intern students with } \\
\text { isolation precautions was high. }\end{array}$} \\
\hline
\end{tabular}

Table 3. The comparison of socio-demographic characteristics of students and the mean IPCS scores

IPCS $X \pm S D$

Age

Gender

Female

Male

Type of the clinic

Internal Medicine

Surgery

Pediatric

The status of receiving training on isolation precautions

Yes

No

Level of knowledge about isolation precautions and nosocomial infections

Good

Moderate

Low

The status of knowing the infection rate of the clinic

Yes

No

The status of providing care to isolated patients during internship

Yes

No

The effect of the pandemic process on the importance attached to isolation precautions $F$

Greatly affected

Little affected

Not affected
$76.10 \pm 10.9$

$76.15 \pm 7.46$

$76.12 \pm 9.39$

$76.26 \pm 11.5$

$75.66 \pm 6.66$

$76.70 \pm 10.6$

$75.91 \pm 9.59$

$76.61 \pm 10.9$

$75.91 \pm 8.18$

$74.22 \pm 8.25$

$78.05 \pm 6.99$

$72.16 \pm 13.2$

$76.70 \pm 10.4$

$75.84 \pm 9.62$

$78.17 \pm 9.28$

$73.04 \pm 9.88$

$63.66 \pm 2.25$
Test and $p$-value

$$
\begin{gathered}
r .0 .075 \\
p=0.361
\end{gathered}
$$

MWU: 2288.0

$\mathrm{p}=0.225$

KW:1.540

$p=0.463$

MWU: 2018.0

$\mathrm{p}=0.352$

KW: 3.224

$\mathrm{p}=0.200$

MWU:1950.0

$\mathrm{p}=0.018$ *

MWU:2204.0

$p=0.247$

*p<0.05, **p<0.001, MWU: Mann-Whitney U Test, KW: Kruskal-Wallis Test, F: Bonferroni Test 
It was determined that there was a very weak positive correlation between the students age and the IPCS score (r:0.075), but this relationship was not statistically significant $(p>0.05)$. There was no statistically significant difference between the mean IPCS score and the variables of gender, the type of the clinic, the training received about isolation precautions and the care provided to the isolated patient ( $p>0.05)$. On the other hand, the difference between the mean IPCS score and the variables of knowing the infection rate of the clinic and the effects of the pandemic process was statistically significant $(p<0.05)$. It was detected that the compliance with isolation precautions was higher among the students who knew the infection rate. The post-hoc statistical analysis to evaluate the effect of the pandemic process on isolation precautions revealed that the group stating that the pandemic process greatly affected the compliance with isolation precautions created a significant difference (Table 3).

\section{DISCUSSION}

Healthcare-associated infections are serious problems that threaten patient safety within the healthcare industry. All health professionals are expected to have appropriate knowledge about these infections and to provide healthcare in accordance with the standard precautions (8, 14). It is extremely important for particularly nurses and nurse candidates, who are personally responsible for the care of patients, to know in which situations the standard and isolation precautions will be applied, and what the precautions include. In addition, their compliance with such precautions in the care and treatment processes is essential for the provision of safe and high-quality health services (15). In this study, intern nurses received 76.11 \pm 9.86 points from the IPCS. The results obtained in the present study shows similarity with the results of the study $(75.45 \pm 9.98)$ by Sakanuz conducted with $2^{\text {nd }}, 3^{\text {rd }}$, and $4^{\text {th }}$ year nursing students (16). It is thought that completing the theoretical education and having more clinical experience may be effective in the slightly higher IPCS scores of the intern nurses. Many studies in the literature reported that the level of compliance with isolation precautions of the nurses and other health workers are good in Turkey (6, $9,12,17,18,19)$. However, the international literature revealed that the knowledge and practices regarding standard precautions among health professionals and students are not sufficient (20-23). Tufail et al. (2017) determined that nurses have a good level of knowledge regarding standard isolation precautions, but their attitudes and practices are not at a sufficient level (14). Yazie et al. also found that health workers' knowledge, attitude and practice scores on infection prevention were low (24). Contrary to these results, in a study conducted with nursing students in the Philippines, it was found that students' awareness of infection control was very high, and the implementation of standard precautions for infection control such as hand washing, proper handling and disposal of contaminated materials was excellent (25). It is considered that socio-cultural factors such as the health and education policies of the countries, personnel insufficiency, the differences in the nursing curriculum, the development level of the countries are the reasons for the difference between the countries. The examination of scores received by intern nurses from the sub-dimensions of the Isolation Precautions Compliance Scale revealed that the students received $21.23 \pm 3.45$ ( $\min : 5-\max : 25)$ from the "Transmission Route", 25.38 3.27 (min: 16 - max: 30) from the "Work and Patient Safety", 16.73 \pm 2.61 (min: 4 max:20) from the "Environmental Control" and 12.76 \pm 1.96 (min:6 - max:15) points from the "Hand Hygiene and Glove Use". The interns have been observed to have a good level of compliance toward transmission route, work and patient safety, environmental control and hand hygiene and glove use. In the study in which Arli and Bakan evaluated the level of compliance of nurses with isolation measures, it was determined that the nurses received $21.65 \pm 3.05$ from "Transmission Route" sub-dimensions of the IPCS, $25.05 \pm 3.48$ from "Work and Patient Safety", 17.08 \pm 2.19 from "Environmental Control" and 12.77 \pm 1.93 from "Hand Hygiene and Glove Use" (9). The scores of IPCS subdimensions, Transmission Route, Work and Patient Safety, Environmental Control, and Hand Hygiene and Glove Use, were detected to be $21.67 \pm 5.13,24.77 \pm 4.58,16.72 \pm 4.49$ and $12.86 \pm 2.47$, respectively for the nurses in Tanyeri's study (26) and $21.31 \pm 3.27,25.08 \pm 3.08,16.74 \pm 2.52$ and $12.31 \pm 2.36$, respectively for the nursing students in Sakanuz's study (16). According to the results mentioned above, it could be concluded that the positive attitudes of nurses and nursing students towards infection control in Turkey are similar, and their compliance with precautions such as transmission route, patient safety, hand hygiene and glove use is at a good level.

In the present study, there was no statistically significant difference between the mean scores of IPCS and the variables of age, gender, the type of the clinic, the training received about isolation precautions and the care provided for isolated patients. In a study conducted with nurses and physicians, Gecit and Ozbayir found that there was no significant difference between the IPCS scores and the variables of age, gender, occupational group, the clinic in which they work, being satisfied with the working conditions and finding professional development sufficient (18). It was reported by Zencir et al. that there was no statistically significant difference between the mean IPCS score of the nurses and the clinics they worked in, marital status, their willingness to do their job, the training they received on infection and the status of having a blood-borne infection before (12). Another study, investigating the compliance with isolation precautions of intensive care physicians and nurses, indicated that there was no statistically significant difference between the IPCS score and the variables of age, gender, occupation, isolation training status, and the unit they worked in (6). The significant difference between compliance with isolation precautions in terms of demographic variables shows that the students comply with isolation precautions at a similar level.

It was detected that the compliance with isolation precautions differed positively in the intern nurses who 
knew the infection rate of the unit where they worked. One-third of the intern nurses were determined to know the infection rate of the unit they worked in. The infection rate is one of the healthcare service quality indicators in the unit. The infection control committee in a hospital monitors the surveillance rate of the units and regularly reports the results obtained to the relevant units. It needs to be pointed out that jointly discussing active surveillance results, problems and solutions by the hospital infection control committee team and unit employees is important in terms of increasing compliance with infection control precautions (27). There was no significant difference between the IPCS scores and knowing the infection rate in the study by Tayran et al. conducted with the nurses. However, there was a significant difference between knowing the infection rate and the IPCS scores, transmission route and environmental control precautions in the physicians. The compliance with isolation precautions was higher in the physicians who knew the infection rate of the unit in which they worked than those who did not (27). It is of the opinion that knowing the infection rate in the unit will contribute to considering the precautions to be taken by reviewing the current situation and increasing the compliance with isolation.

The present study was carried out during the COVID-19 pandemic and it was determined that the pandemic process positively increased the compliance with isolation precautions. The usage rate of protective equipment (gloves, masks, aprons or overalls) in all clinics has increased with the pandemic process. It is an expected result that intern nurses pay more attention to these precautions to protect themselves, their families and patients they provide care during this difficult time.

\section{CONCLUSION}

In conclusion, the present study carried out with the intern nurses showed that the participants' compliance with isolation precautions was at a good level. It was determined the difference between the compliance level of isolation precautions and the variables of age, gender, the type of the clinic, the training received regarding isolation precautions and the care provided to the isolated patient was not statistically significant. However, the difference between the compliance with isolation precautions and the variables of the pandemic process and knowing the infection rate of the institution was detected to be significant.

It is recommended to update the knowledge and performance of intern nurses by providing in-service training programs for specific groups found to be at risk for reducing nosocomial infections, emphasize the importance of the use of the latest and evidence-based practices of infection control in current education/training programs, and to conduct researches with larger sample groups and share the results with hospital managements.

Financial disclosures: The authors declared that this study hasn't received no financial support.
Conflict of Interest: The authors declare that they have no competing interest.

Ethical approval: Ethical approval from the Health Sciences Scientific Research and Publication Ethics Committee of Inonu University (2021/1554)

\section{REFERENCES}

1. Gadade M, Singh MV, Toradmal MR, et al. A Study to assess the knowledge regarding nosocomial infection among b. sc. nursing students in selected nursing institutions of pune city. J Med Science and Clin Res. 2018;6:58-62.

2. Khan HA, Ahmad A, Mehboob R. Nosocomial infections and their control strategies. Asian Pacific J Tropical Biomedicine. 2015;5:509-14.

3. Lambert ML, Suetens C, Savey A, et al. Clinical outcomes of health-care-associated infections and antimicrobial resistance in patients admitted to European intensivecare units: a cohort study. Lancet Infectious Diseases. $2011 ; 11: 30-8$

4. Mohandass B, Kaur A, Timsy HK, et al. Assess the knowledge, practice and attitude regarding nosocomial infections and their preventive among health care staf. Medico Legal Update. 2021;21:168-73.

5. Pegram A, \& Bloomfield J. Infection prevention and control. Nursing Standard. 2015;29:37.

6. Erden S, Kahraman BB, \& Bulut H. Evaluation of compliance of physicians and nurses with isolation precautions in intensive care units. Gümüşhane University Journal of Health Sciences. 2015;4:388-98.

7. Yüceer S, Demir S. Prevention of nosocomial infections in intensive care unit and nursing practices. Dicle Med J. 2009;36:226-32.

8. Mohapatra A, Sarangi L. Assessment of knowledge and practice to control nosocomial infection, among the staff nurses, Hi-Tech Medical College \& Hospital, Bhubaneswar. Indian Journal of Community Health. 2018;30:385-9.

9. Arli SK, \& Bakan AB. Nurses' compliance with isolation precautions and the affecting factors. Applied Nursing Res. 2017;38:175-8.

10. Kurt D, \& Dalkıran SS. Determining the compliance of intern nursing students with isolation precautions in the COVID-19 pandemic period. Bezmialem Science. 2021;1-6.

11. Lee KA, Kim HS, Lee YW, Ham OK. Factors influencing compliance with standard precautions in intensive care unit and emergency room nurses. Journal of Korean Academy of Fundamentals of Nursing. 2012;19:302-12.

12. Zencir G, Bayraktar D, Khorshid L. Nurses' compliance with isolation precautions worked in a public hospital. Journal of Ege University Nursing Faculty (JEUNF). 2013;29:61-70.

13. Tayran N, Ulupınar S. Development of a scale study: validity and reliability of a scale compliance with isolation precautions. Florence Nightingale Journal of Nursing. 2011;19:89-98.

14. Tufail S, Afzal M, Perveen K, et al. Knowledge, Attitude and Practice towards standard isolation precautions among registered Nurses. Saudi Journal of Medical and Pharmaceutical Sciences. 2017;3:534-44. 
15. Akkaya HA. Investigation of the Compliance of Nurses Working in a Private Health-care Institution to Isolation Precautions. Acıbadem Mehmet Ali Aydınlar University, Institute of Health Science, Master Thesis, 2021, İstanbul.

16. Sakanuz M. Comparison of nursing and medical students' hand hygiene beliefs, hand hygiene practices and compliance with isolation measures. Manisa Celal Bayar University, Institute of Health Science, Master Thesis, 2019, Manisa.

17. Elmas Y. The Correlation Between In-Service Training by Nurses' Compliance with Isolation Precautions. Necmettin Erbakan University, Institute of Health Science, Master Thesis, 2019, İstanbul.

18. Geçit S, Özbayır T. Compliance of nursing and physicians to isolation precautions. Journal of Ege University Nursing Faculty (JEUNF). 2020;36:163-73.

19. Şatır DG, Güneri SE, Öztürk R, Maraş GB, Mertoğlu A, Sevil Ü. Evaluating the compliance and factors affecting with isolation precautions of nurses: Izmir Sample. Tepecik Eğit ve Araşt. Hast Dergisi. 2019;29:218-22.

20. Eskander HG, Morsy WYM, \& Elfeky HAA. Intensive care nurses' knowledge \& practices regarding infection control standard precautions at a selected Egyptian cancer hospital. Prevention. 2013;4:160-74.

21. Fayaz SH, Higuchi M, Hirosawa $\mathrm{T}$, et al. Knowledge and practice of universal precautions among health care workers in four national hospitals in Kabul, Afghanistan. The Journal of Infection in Developing Countries. 2014;8:53542.
22. Karim J, Al-Saraji M, Al-Mousawi F, et al. Knowledge and self-reported practice of universal precautions among Kuwait University medical students in their clinical years. Medical Principles and Practice. 2012;21:328-33.

23. Motamed N, Baba Mahmoodi F, et al. Knowledge and practices of health care workers and medical students towards universal precautions in hospitals in Mazandaran Province. EMHJ - Eastern Mediterranean Health Journal 2006;12:653-61.

24. Yazie TD, Sharew GB, Abebe W. Knowledge, attitude, and practice of healthcare professionals regarding infection prevention at Gondar University referral hospital, northwest Ethiopia: a cross-sectional study. BMC Research Notes. 2019;12:1-7.

25. Jael SA, Maristela TAE, Alano JCR,et al. Awareness and Practice of Standard Precaution for Infection Control among Student Nurses. In Abstract Proceedings International Scholars Conference. 2019; 7:417-133.

26. Tanyeri, K. Determination of Compliance of Nurses to Isolation Measures in Prevention of Hospital Infections, Institue of Health Sciences, Near East University, Department of Nursing. Master Thesis, Nicosia, 2018.

27. Tayran N. The Compliance of Nurses and Physicians with the Isolation Precautions. Marmara University, Institue of Health Sciences. Master Thesis, İstanbul, 2010. 